\title{
KAJIAN DESAIN PADA TEKSTIL TIRUAN BATIK DI SIDOMULYO NGAWI SEBAGAI TEKSTIL UNTUK SERAGAM
}

\author{
Silvia Khoiru Azizah ${ }^{1 *}$, Tiwi Bina Affanti2*
}

\author{
Program Studi Kriya Tekstil Fakultas Seni Rupa dan Desain \\ Universitas Sebelas Maret \\ Jl. Ir. Sutami, No. 36, Kentingan, Kec. Jebres, Kota Surakarta, Kode Pos 57126 \\ Jawa Tengah. Indonesia \\ Email: silviakhoiru999@student.uns.ac.id,tiwibina@staff.uns.ac.id
}

\begin{abstract}
Abstrak
Kerajinan batik di Kabupaten Ngawi muncul pertama kali di Tempurejo, Desa Banyubiru yang bernama Griya Batik Sidomulyo. Secara visual desain tampak rapi dan komposisi coraknya bagus, serta hasil produksinya lebih awet dan tidak mudah luntur. Produk 'tiruan batik' telah diproduksi sebagai seragam instansi pemerintah maupun swasta di Kabupaten Ngawi. Permasalahan yang dibahas bertujuan untuk mengetahui latar belakang Griya Batik Sidomulyo memproduksi tiruan batik sebagai tekstil untuk seragam dan aspek-aspek yang dipertimbangkan dalam merancang seragam tiruan batik. Metode dalam penelitian ini menggunakan metode kualitatif deskriptif dengan pendekatan desain. Pendekatan desain digunakan untuk mengkaji kain tiruan batik print malam dingin di Griya Batik Sidomulyo. Hasil penelitian ini adalah latar belakang Griya Batik Sidomulyo memproduksi tiruan batik diawali dengan memproduksi batik tulis. Produksi tiruan batik print malam dingin sejak tahun 2010 hingga sekarang. Upaya memproduksi kain tiruan batik agar mampu memenuhi pasar dengan harga yang relatif lebih murah. Produksi kain tidak hanya memenuhi persyaratan desain, namun harus sesuai dengan permintaan pasar maupun pembeli. Aspek-aspek yang dipertimbangkan dalam merancang memiliki persamaan dan perbedaan pada fungsional, estetika, bahan, dan proses produksi. Pertimbangan lainnya diperlukan adanya selera konsumen, trend mode, pemasaran untuk terjalinnya komunikasi.
\end{abstract}

Kata Kunci: desain, tiruan batik, sidomulyo, seragam.

\section{Abstract}

Batik craft in Ngawi Regency first appeared in Tempurejo, Banyubiru Village, which is called Griya Batik Sidomulyo. 'Batik Imitation' products have been produced as uniforms for government or private agencies in Ngawi Regency. The problems discussed are animed at determining the background of Griya Batik Sidomulyo's production of batik imitations as textiles for uniforms and the aspects considered in designing batik imitation uniforms. The method in this research uses descriptive qualitative methods with a design approach. The research location was conducted at Griya Batik Sidomulyo Ngawi. The design approach is used to study the imitation of cold wax printed batik cloth. The result of this study are the background of Griya Batik Sidomulyo producing batik imitation, beginning with producing hand-written batik. Production of cold wax printed batik imitations from 2010 until now. Efforts to produce imitation batik fabrics to be able to meet market at a relatively cheaper price. Fabric production does not only meet design requirements but must be by market demands dan buyers. The aspects considered in designing have similarities and differences in the functional, aesthetics, materials, and production processes. Other conciderations require consumer tastes, trends mode, marketing to establish communication.

Keywords: design, batik imitation, sidomulyo, uniform.

\section{PENDAHULUAN}

Kerajinan batik Ngawi muncul pertama kali di Sukorejo / Tempurejo, Desa Banyubiru, Kecamatan Widodaren, Kabupaten Ngawi, Provinsi Jawa Timur yang bernama Griya Batik Sidomulyo pada tahun 1989. Di samping memproduksi batik tulis, Batik Sidomulyo juga memproduksi "Tiruan Batik" yang merupakan pesanan dari lembaga pemerintah maupun swasta di Kabupaten Ngawi dan luar daerah Kabupaten Ngawi.
Produk "tiruan batik" tersebut divisualkan dalam tekstil pakaian untuk seragam. Selama satu tahun terakhir Batik Sidomulyo telah menerima pesanan seragam lebih dari 20 lembaga diantaranya, seragam batik untuk 16 Bupati di Jawa Timur khususnya dari Kabupaten Ngawi, Dinas Pariwisata Kabupaten Ngawi, Rumah Sakit Gigi di Kabupaten Ngawi, PT Amsol Batam, dan 


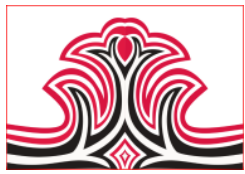

yang terakhir seragam batik kolaborasi dengan Griya Batik Enjang Pelangi Ngawi untuk Pemda Kabupaten Ngawi.

Hasil wawancara yang didapatkan dari beberapa lembaga yang telah memesan di Batik Sidomulyo merasa puas karena sesuai dengan hasil pesanannya. Secara visual desain tampak rapi dan komposisi coraknya bagus, serta hasil produksinya lebih awet dan tidak mudah luntur. Tidak heran jika Batik Sidomulyo merupakan produsen batik pertama di Kabupaten Ngawi dan telah menjadi langganan Bupati Kabupaten Ngawi yaitu Bapak Ir. H. Budi Sulistyono di setiap event pameran. Dari uraian tersebut di atas, terbukti bahwa Griya Batik Sidomulyo dianggap mampu memvisualkan desain seragam sesuai yang dikehendaki konsumen. Hal tersebut menjadi daya tarik penulis untuk mengkaji faktor-faktor yang dipertimbangkan oleh Batik Sidomulyo untuk memuaskan konsumennya dalam pemesanan kain seragam khususnya "tiruan batik".

Kajian ini menggunakan pendekatan desain untuk menjelaskan latar belakang Griya Batik Sidomulyo memproduksi "tiruan batik" untuk seragam dan menguraikan aspek-aspek yang dipertimbangkan dalam mengerjakan seragam tiruan batik. Permasalahan ini dibatasi dengan produk "tiruan batik" selama tahun 2019-2020.

\section{KAJIAN TEORI}

\section{Desain}

Menurut Widagdo tahun 1993 pada dalam buku Metodologi Penelitian Budaya Rupa (dalam Sachari, 2005: 7), desain adalah salah satu manifestasi kebudayaan yang berwujud dan merupakan produk nilai untuk kurun waktu tertentu. Desain dikaitkan dengan nilai kontekstual yang menyuarakan kebudayaan, dengan membuktikan bahwa desain bukan hanya mampu memecahkan masalah manusia tapi juga bermuatan nilai-nilai yang membangun peradaban. Berpijak dari paparan di atas pendapat lain mengatakan bahwa desain tidak bisa dilepaskan dengan prinsipprinsip dasar seni rupa dimana ada beberapa item diantaranya keselarasan/irama/ritme, kesatuan, dominasi, keseimbangan, keserasian, kesederhanaan, dan kejelasan (Paramita et al., 2020 dalam Utoyo, 2020: 420).

Menurut Colin Clipson dalam buku Tinjauan Desain Tekstil (2017: 40), proses desain merupakan menterjemahkan suatu kebutuhan, tujuan, gagasan pemakai yang sesuai dengan spesifikasi teknologi, sosial, dan lingkungan, serta mempertimbangkan
Gorga : Jurnal Seni Rupa

Volume 10 Nomor 01 Januari-Juni 2021

p-ISSN: 2301-5942 | e-ISSN: 2580-2380

kegunaan produk atau jasa dalam lingkungannya yang mengacu kepada pasar dan pembeli. Dalam teori Colin Clipson juga dijelaskan tahapan penting dalam rangkaian proses desain tekstil antara lain aspek fungsional, aspek estetika, aspek bahan, dan aspek proses. Pertimbangan lainnya untuk melengkapi aspekaspek pokok tersebut yakni selera konsumen, trend mode, dan pemasaran.

\section{Batik}

Definisi batik SNI 0239: 2014, Batik-Pengertian dan istilah "Batik adalah kerajinan tangan sebagai hasil pewarnaan secara perintangan menggunakan malam atau lilin panas sebagai perintang warna dengan alat utama canting tulis atau cap untuk membentuk motif tertentu " (BSN: 2014). Penggolongan corak batik berdasarkan bentuknya menurut Wulandari (2011: 106-112) dibagi menjadi dua golongan yaitu corak geometris dan non geometris. Batik tergolong menjadi beberapa jenis menurut teknik pembuatannya. Menurut Lisbijanto (2013: 10-12) ada tiga jenis batik antara lain batik tulis, batik cap, dan batik lukis.

"Motif sangat berhubungan erat dengan pola karena motif merupakan pangkal atau dasar atau titik tolak dari terbentuknya sebuah pola apabila motif tersebut mengalami pengulangan secara simetris atau non simetris" (Affanti, 2007: 19). Dalam ornamen, pola merupakan bentuk pengulangan dari motif yang artinya sejumlah motif akan diulang-ulang secara struktural dipandang sebagai pola. Sebuah pola merupakan susunan motif, yang dapat diulang dan diatur sehingga membentuk pola yang baru, sedangkan pola lama menjadi motifnya (Sunaryo, 2009: 14).

Menurut unsur-unsurnya, motif batik dibagi menjadi dua bagian utama (Susanto, 1980: 212) yakni Ornamen motif batik, yaitu gambar pokok yang merupakan inti dari motif tersebut antara lain ornamen utama dan ornamen pengisi bidang. Isen-isen batik, yaitu berupa titik-titik, garis-garis, gabungan titik dan garis, yang berfungsi untuk mengisi ornamen-ornamen dari motif atau mengisi bidang diantara ornamen-ornamen tersebut dan memperindah motif secara keseluruhan.

\section{Tiruan Batik}

Pengertian "Tiruan batik" SNI 8184, 2015 adalah produk manual, semimasial, dan atau masinal yang dibuat dengan menggunakan alat utama screen rakel dan atau alat lain untuk melekatkan pewarna, bahan kimia cabut warna, dan atau malam dingin serta paduannya untuk membentuk motif (BSN, 2015). 
Gorga : Jurnal Seni Rupa

Volume 10 Nomor 01 Januari-Juni 2021

p-ISSN: 2301-5942 | e-ISSN: 2580-2380

Proses pengerjaan antara batik dengan tiruan batik berbeda, waktu pengerjaan batik lebih lama. Pada satu lembar kain batik membutuhkan waktu pengerjaan selama satu bulan, sedangkan pada tiruan batik print malam dingin pengerjaannya membutuhkan waktu 4-5 hari. Batik dengan teknik malam dingin dianggap sebagai tiruan batik ( , 2019: 4). Tiruan batik meliputi beberapa jenis antara lain print warna, cabut warna, print malam dingin, serta print mesin.

Perbedaan antara tiruan batik print malam dingin dengan batik terletak pada pelekatan malam (lilin). Menurut Sulaeman dan Suhartini (1988: 25-29), "pembuatan lilin batik pasta menggunakan bahan lilin seperti : damar atau mata pancing, gondorukem, kote, paraffin, dan terpentin. Bahan-bahan tesebut dicampur dan dan dipanaskan sehingga memperoleh lilin batik pasta. Lilin batik selanjutnya diencerkan dengan pelarut organis seperti aseton, tolunena, n-heksana, dan terpentin". Produksi malam dingin di Griya Batik Sidomulyo menggunakan bahan utama malam atau lilin sisa pelorodan dicampur dengan bahan lilin. Campuran tersebut diencerkan dengan larutan bensin.

\section{Seragam}

Griya Batik Sidomulyo memanfaatkan tiruan batik print malam dingin untuk merancang seragam instansi maupun perorangan. Pakaian memiliki fungsi untuk menyesuaikan diri dengan lingkungan sosialnya. Fungsi sosial menyebabkan manusia untuk berpenampilan dengan mempertimbangkan kepatutan dan kesopanan menurut nilai moral yang ada di masyarakat. Sebuah lingkungan sosial tidak diizinkan manusia untuk telanjang sehingga dalam bersosialisasi membutuhkan pakaian yang pantas (Van Hoed, 2008: 141)

Ibrahim (2007: 241) menyatakan bahwa, "fashion, pakaian, busana sudah menjadi bagian penting dari gaya trend, penampilan keseharian sebagai fenomena budaya dan komunikasi, fashion sesungguhnya dapat berucap banyak tentang identitas pemakainya". Pengertian pakaian adalah barang apa yang dipakai, sedangkan seragam adalah satu ragam atau corak dan bentuk. Apabila dirangkaikan menjadi pakaian seragam adalah pakaian yang serupa warna dan guntingannya, misalnya kemeja, blouse, jas, celana, rok, dan pakaian olah raga (Suharso dan Ana, 2005: 357).

\section{Griya Batik Sidomulyo, Ngawi, Jawa Timur}

Griya Batik Sidomulyo adalah salah satu perusahaan batik pertama di Kabupaten Ngawi yang berlokasi di Tempurejo/Sukorejo RT 07/RW 01, Desa Banyubiru, Kecamatan Widodaren, Kabupaten Ngawi. Batik
Sidomulyo telah didirikan oleh Bapak Suwandi lebih dari 30 tahun dan mengalami perkembangan yang pesat sekitar tahun 2011 ketika dari Dinas Kabupaten Ngawi memprogramkan kepada seluruh pegawai PNS harus mengenakan batik Ngawi.

\section{Teori Desain}

Upaya Griya Batik Sidomulyo dalam memproduksi kain "tiruan batik" print malam dingin dilatarbelakangi adanya kemajuan teknologi, sehingga mampu memproduksi lebih cepat dan sesuai dengan desain pesanan konsumen. Perancangan desain tekstil diperlukan adanya pertimbangan desain. Pertimbangan desain dalam kajian ini menggunakan Teori Colin Clipson dalam Tinjauan Desain Tekstil bahwa aspekaspek yang dipertimbangkan untuk merancang seragam tiruan batik antara lain aspek fungsional, estetika, bahan, dan proses. Pertimbangan lainnya untuk melengkapi aspek utama tersebut yakni selera konsumen, trend mode, dan pemasaran (Rizali, 2017: $58)$.

\section{METODE PENELITIAN}

Penelitian ini menggunakan metode penelitian kualititatif deskriptif dengan menekankan catatan dan gambar sebagai informasi yang bergantung pada perspektif teoritis (Sutopo, 2003: 35). Lokasi penelitian di Griya Batik Sidomulyo Ngawi di Tempurejo/Sukorejo RT 07/RW 01, Banyubiru, Widodaren, Ngawi sebagai tempat produksi "tiruan batik" khususnya sebagai tekstil untuk seragam. Lokasi lainnya di Alun-alun Kabupaten Ngawi ketika event pameran batik. Pencarian data dilakukan di lakukan di berbagai instansi di Kabupaten Ngawi yang telah memesan "tiruan batik" print malam dingin.

Teknik sampling yang digunakan dalam penelitian ini bersifat "purposive sampling" berdasarkan pada landasan teori yang digunakan, keingintahuan pribadi, dan memilih informannya secara mendalam serta dapat dipercaya. Sampel objek yang diteliti didasarkan jumlah kain "tiruan batik" print malam dingin sebagai seragam instansi tahun 2019-2020.

Strategi dan bentuk pendekatan penelitian ini jenis kualitatif deskriptif yang studi kasusnya mengarah pada pendeskripsian secara rinci dan mendalam tentang latar belakang Griya Batik Sidomulyo memproduksi "tiruan batik" dan perwujudan aspek-aspek yang dipertimbangkan dalam merancang "tiruan batik" untuk seragam.

Sumber data yang digunakan dalam penelitian ini antara lain : (1) informan utama yakni Suwandi selaku 
pemilik Griya Batik Sidomulyo, Miatun selaku karyawan di bagian pencantingan, Triastutik selaku karyawan di bagian perwarnaan, Bilal selaku karyawan di bagian penyablonan, dan instansi yang telah memesan seragam (2) produk batik yang telah dipesan oleh beberapa instansi seperti "tiruan batik" pola Wahyu Ngawiat untuk seragam ibu-ibu Deskranasda Ngawi, pola Gunungan Ngawi untuk Dinas Pariwisata Pemuda dan Olahraga Ngawi, pola Bulus untuk Rumah Sakit Gigi di Ngawi, dan pola Bambu untuk PLKB Ngawi. (3) benda, gambar, dan rekaman sebagai hasil wawancara. (4) dokumen dan arsip dari Perpustakaan Universitas Sebelas Maret, dokumen pribadi berupa foto-foto produk dari pemilik Griya Batik Sidomulyo, dan piagam penghargana kegiatan workshop atau pameran.

Teknik pengumpulan data dilakukan dengan observasi di Griya Batik Sidomulyo Ngawi untuk mengakaji produk "tiruan batik", wawancara dengan sifat "open ended" mengarah pada pendalaman informasi, dan arsip serta dokumen yang lebih ditekankan pada foto atau gambar objek penelitian. Data yang telah dikumpulkan harus terbukti kebenarannya dengan dilakukan validitas data teknik trianggulasi data. Teknik ini dilakuakn dengan memanfaatkan sumber yang berbeda untuk menggali data yang sejenis, sehingga data akan teruji kebenarannya.

Penelitian ini menggunakan teknik analisis data metode kualitatif model analisis interaktif yakni reduksi data, sajian data, dan penarikan kesimpulan serta verifikasinya (Sutopo, 2002: 91). Reduksi data merupakan proses analisis untuk memfokuskan data yang penting. Sajian data merupakan bentuk narasi deskripsi yang didaptkan kesimpulan penelitian. Pada waktu pengumpulan data sudah berakhir, dilakukan penarikan kesimpulan dan verifikasi data.

\section{HASIL DAN PEMBAHASAN}

\section{Hasil}

Griya Batik Sidomulyo adalah perusahaan batik pertama di Kabupaten Ngawi yang berlokasi di Tempurejo/Sukorejo RT 07/RW 01, Desa Banyubiru, Kecamatan Widodaren, Kabupaten Ngawi. Griya Batik Sidomulyo telah didirikan oleh Suwandi pada tahun 1989 yakni lebih dari 30 tahun. Pada tahun 1995, Griya Batik Sidomulyo semakin dikenal dan populer di kalangan masyarakat Ngawi.

Awalnya Suwandi selaku pemilik Griya Batik Sidomulyo bekerja di perusahaan-perusahaan batik yang ada di Solo, sedangkan Miatun selaku istri dari Suwandi belajar membatik di salah satu perusahaan batik di Sragen. Pengalaman dari perusahaanperusahaan batik seperti Batik Keris dan Batik Semar sebagai modal awal untuk memproduksi kain batik pertama di Kabupaten Ngawi.

Griya Batik Sidomulyo memproduksi kain batik tulis seperti motif Sidomukti, Bokor Kencono, Gringsing, dan batik tulis dengan motif tradisi lainnya. Penerapan desain tersebut pada jarik dan selendang dengan pangsa pasar penjual kain di pasar-pasar tradisional daerah sekitar Kecamatan Widodaren dan Ngrambe. Motif lain yang diproduksi ialah motif flora fauna ciri khas dari Kabupaten Ngawi yang dikenal dengan Motif Ngawiat.

Sejak tahun 2010 Griya Batik Sidomulyo mulai memproduksi kain "tiruan batik" dengan print malam dingin. Upaya memproduksi kain "tiruan batik" agar mampu memenuhi pasar dengan harga yang relatif lebih murah daripada batik tulis. Beberapa alasan lainnya antara lain : (1) produksi kain tidak hanya memenuhi persyaratan desain, namun harus sesuai dengan permintaan pasar maupun pembeli. (2) produksi kain batik tulis memerlukan biaya yang cukup mahal, sehingga produksi kain memerlukan teknik lain yang memerlukan biaya relatif murah. (3) keinginan masyarakat untuk memakai pakaian batik sangat tinggi mengakibatkan perlunya produksi kain yang cepat tanpa menghilangkan kualitas produksi kain. (4) tenaga kerja yang sedikit, dengan teknologi print malam dingin dapat mempercepat proses produksi tanpa harus menambah tenaga kerja.

Sekitar tahun 2011 Griya Batik Sidomulyo semakin berkembang pesat, ketika dari Dinas Kabupaten Ngawi memprogramkan kepada seluruh pegawai PNS harus mengenakan batik Ngawi. Berdasarkan surat dari Dewan Pengurus Nasional Korps Pegawai Republik Indonesia, Nomor : SE-08/KU/XII/2011 tentang penyampaian peraturan DP KORPRI Nasional Nomor 02 Tahun 2011 Tentang Pakaian Seragam Batik Korps Pegawai Republik Indonesia. Nama Griya Batik Sidomulyo milik Suwandi semakin dikenal masyarakat dan pegawai-pegawai di Kabupaten Ngawi.

Pada pertemuan seluruh pemilik UMKM di Kabupaten Ngawi, Suwandi mengusulkan untuk produksi batiknya agar mendapat bantuan dari pemerintah. Pada tahun 2016 usulan tersebut diterima dengan menghasilkan sumbangan dari pemerintah Kabupaten Ngawi berupa alat dan bahan pembatikan.

Desain "tiruan batik" dengan print malam dingin, awalnya hanya dibuat pada satu desain yaitu Motif Gringsing. Motif tersebut dijadikan sebagai selendang 
dan jarik. Kain produksi yang mulanya menggunakan teknik batik tulis, kini diaplikasikan dengan teknik paduan "tiruan batik" print malam dingin.

Proses pengerjaan antara batik tulis dengan "tiruan batik" berbeda, waktu pengerjaan batik lebih lama daripada tiruan batik. Pada satu lembar kain batik tulis membutuhkan waktu pengerjaan selama satu bulan, sedangkan pada "tiruan batik" dengan print malam dingin membutuhkan waktu 4-5 hari. Adanya teknologi sablon atau print malam dingin, menyebabkan efisiensi tepatnya waktu proses produksi kain. Banyaknya permintaan kain "tiruan batik", penggunaan teknologi berupa alat penyablonan sangat dibutuhkan untuk mempermudah produksi kain.

Saat ini, Griya Batik Sidomulyo telah mengerjakan lebih dari 30 desain untuk dijual umum dan pesanan untuk seragam. Rancangan desain tersebut merupakan desain Suwandi dan desain gabungan Suwandi dengan konsumen. Rancangan desain Suwandi antara lain desain Wahyu Ngawiat, Gunungan Ngawi, dan alam sekitar. Rancangan desain gabungan Suwandi dan konsumen yaitu motif yang disesuaikan dengan pesanan konsumen.

Produk "tiruan batik" dengan print malam dingin telah dijual di pasar-pasar daerah, selain itu kain tersebut telah dipesan oleh instansi pemerintah, instansi swasta, dan perorangan. Berbagai instansi yang telah memesan antara lain Deskranasda Kabupaten Ngawi, Dinas Pariwisata Pemuda dan Olahraga Kabupaten Ngawi, Bupati Ngawi, PLKB Ngawi, PT Amsol Batam, Rumah Sakit Gigi Ngawi dan SMA N 1 Jogorogo. Produk Griya Batik Sidomulyo telah didistribusikan hingga Rembang, Cilacap, dan Kalimantan Timur.

Produk "tiruan batik" Griya Batik Sidomulyo yang telah dipesan sebagai seragam dapat diklasifikasikan antara lain: (1) Pola Wahyu Ngawiat, mempunyai satu desain dengan warna latar yang berbeda sesuai dengan pesanan konsumen. Warna latar pada pola Wahyu Ngawiat antara lain warna merah, biru, dan hijau. (2) Pola Gunungan Ngawi, mempunyai motif mirip gunung dengan bagian tengah meruncing dan di dalamnya terdapat motif flora. Motif latar pengisi Gunungan Ngawi antara lain padi, lerek, ataupun logo instansi. Warna pada pola Gunungan Ngawi disesuaikan oleh pesanan konsumen. (3) Pola Pesanan Konsumen, Desain kain dipesan dan disesuaikan oleh pesanan konsumen. Kain yang dipesan merupakan kombinasi antara desain Pemilik Griya Batik Sidomulyo dengan instansi yang memesan. (4) Pola Alam Sekitar, menceritakan flora fauna khas
Kabupaten Ngawi maupun tempat wisata di Kabupaten Ngawi. Motif-motif tersebut biasa dikenal sebagai Motif Ngawiat.

\section{Pembahasan}

Setiap desain terdapat faktor yang harus dipenuhi termasuk untuk pelayanan fisik dan psikis, yaitu bahwa desain harus fungsional, aman, dan nyaman bila dipakai. Desain tekstil merupakan salah satu upaya untuk meningkatkan produk tekstil agar mempunyai nilai estetis dan ekonomis yang tinggi. Bukan hanya aspek visual, melainkan membutuhkan aspek-aspek untuk mencapai hasil yang bernilai dan diperlukan oleh masyarakat.

Aspek-aspek pertimbangan kreatif tersebut diperlukan oleh Batik Sidomulyo untuk merancang desain dan memenuhi pesanan konsumen. Aspek-aspek tersebut antara lain aspek fungsional, estetis, bahan, dan proses atau teknis produksi. Pertimbangan lain yang diperlukan yakni selera konsumen, trend mode, dan pemasaran.

Produk kain "tiruan batik" print malam dingin akan dibahas dengan klasifikasi dengan mengambil satu produk di tahun 2019-2020. Kain "tiruan batik" tersebut antara lain Motif Wahyu Ngawiat untuk seragam Deskranasda Kabupaten Ngawi, Motif Gunungan untuk seragam Dinas Pariwisata Pemuda dan Olahraga Kabupaten Ngawi, Motif Bulus untuk seragam Rumah Sakit Gigi di Ngawi, dan Motif Bambu untuk seragam PLKB Ngawi.

\section{1). Motif Wahyu Ngawiat Seragam dari Deskranasda Kabupaten Ngawi}

Fungsional, Motif Wahyu Ngawiat dipesan sebagai seragam ibu-ibu pegawai Deskranasda Kabupaten Ngawi. Kain seragam tersebut digunakan sebagai baju seragam wanita.

Estetika atau Keindahan, Desain Wahyu Ngawiat dirancang oleh Suwandi selaku pemilik Griya Batik Sidomulyo. Desain kain "tiruan batik" Wahyu Ngawiat memiliki corak hias non geometris. Penyusunan Motif Wahyu Ngawiat menggunakan prinsip irama pengulangan motif, warna, dan ukuran motif yang sama secara bergantian. Penyusunan kesatuan Motif Wahyu Ngawiat tampak pada kesamaan-kesamaan motif, penebaran warna latar dan motif yang ajeg, dan muncul kerapatan-kerapatan pada motif maupun warna. Keseluruhan motif tampak seimbang dan simetris adanya hiasan pinggiran di tepi bawah kain. 


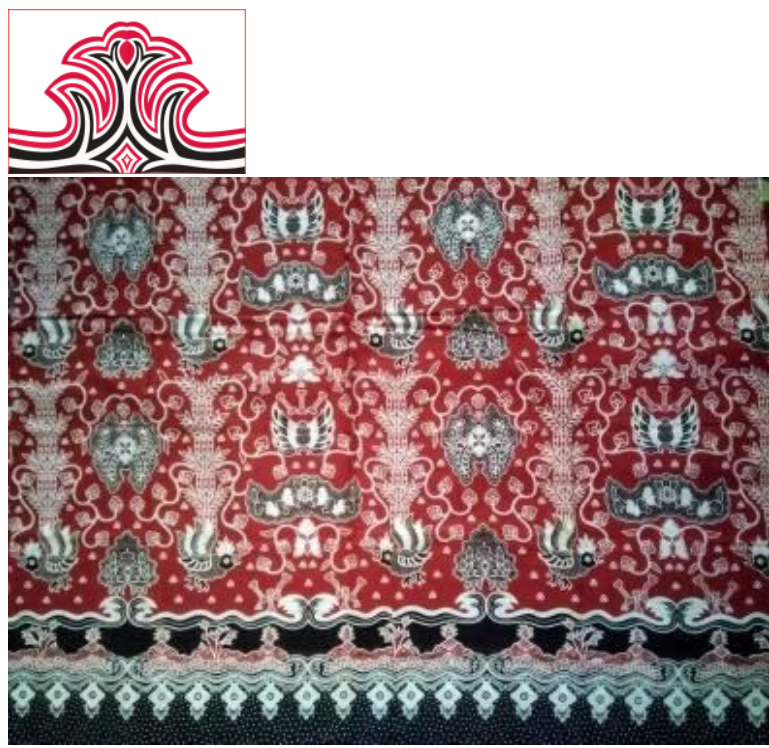

Gambar 1. Kain “Tiruan Batik” Wahyu Ngawiat untuk Seragam Deskranasda Ngawi

(Azizah, 2020)

Motif utama desain "tiruan batik" Motif Wahyu Ngawiat divisualkan dengan inspirasi batik Wahyu Tumurun. Beberapa motif yang divisualkan pada pola tersebut antara lain motif gurda, motif mahkota, motif iber-iberan atau hewan terbang, motif tumbuhan pinang, motif bambu, motif pohon hayat atau kehidupan, dan motif tumbuhan semen (sulur). Motif ayam bekisar sebagai visualisasi dari motif iber-iberan dan motif bambu sebagai sebagai visual dari nama Ngawi yakni 'awi' yang artinya bambu serta menjadi pangkal tumbuhan sulur. Isen-isen pada motif utama berupa isen-isen mata dara, ceceg, dan ceceg.

Motif pengisi "tiruan batik" Wahyu Ngawiat berupa fosil manusia purba dan motif pengisi pada hiasan pinggiran berupa motif-motif khas Ngawi yaitu motif kali tempuk, fosil manusia purba, bebatuan dan tanah yang menjadi tempat tumbuhnya tanaman jati. Garis pada motif kali tempuk menjadi pembatas antara hiasan pinggiran dengan motif utama Wahyu Ngawiat. Susunan motif pengisi sekaligus sebagai hiasan pinggiran dirangkai memanjang dan berkesinambungan. Isen-isen pada motif pengisi berupa isen-isen gringsing sisik, mata dara, sawut, dan ceceg.

Hasil goresan malam dingin pada pola Wahyu Ngawiat membentuk garis lengkung yang bersifat grafis (calligraphic mark). Penggambaran motif dilakukan dengan modifikasi stilasi tanpa meninggalkan unsur utama pada motif Wahyu Tumurun. Bentuk garis lengkung sebagai penggambaran motif Kali Tempuk sebagai penghubung antara motif utama Wahyu Tumurun dan hiasan pinggiran sebagai ciri khas Ngawi.

Pemilihan warna untuk seragam Deskranasda Kabupaten Ngawi ialah dominan warna merah dan warna motif lainnya yakni warna hitam dan putih.
Gorga : Jurnal Seni Rupa

Volume 10 Nomor 01 Januari-Juni 2021

p-ISSN: 2301-5942 | e-ISSN: 2580-2380

Warna tersebut secara psikologis jenis warna hue atau rona warna. Warna pada Pola Wahyu Ngawiat tampak cerah dengan dominan merah. Kesatuan warna merah divisualisasikan dengan penetralan (neutralizing) menggunakan warna hitam dan putih. Warna putih hasil dari penyablonan malam dingin memberi kesan batas antara warna latar dengan motif.

Bahan, bahan kain untuk seragam "tiruan batik" Wahyu Ngawiat menggunakan bahan kain mori primissima 'Tari Kupu-Kupu'. Kain mori tersebut merupakan jenis kain mori dengan benang $100 \%$ cotton $50 s$, sehingga kualitas kain lembut, nyaman, dan mudah diaplikasikan pada pewarna remasol. Bahan lain sebagai pelengkap untuk kain "tiruan batik" yakni pewarna remasol, pasta malam dingin, dan waterglass untuk fiksasi kain. Pewarna remasol yang digunakan untuk "tiruan batik" Wahyu Ngawiat antara lain warna merah dan hitam. Pewarna remasol tersebut dibeli dari Toko tekstil 'Santoso' di Solo. Komposisi pencampuran warna dilakukan dengan cara eksperimen warna agar tersebut sesuai dengan desain.

Griya Batik Sidomulyo memproduksi bahan malam dingin dengan menggunakan malam atau lilin sisa dari pelorodan. Malam sisa pelorodan dicampurkan dengan bahan lilin seperti getah pohon damar (mata kucing), gondorukem, kote, paraffin, dan terpentin. Campuran tersebut diencerkan dengan larutan bensin, kemudian diencerkan menggunakan mesin bor hingga larutan tercampur rata.

Proses atau Teknis Pelaksanaan, (a) pra produksi, dengan menyiapkan desain ukuran 1x2 meter sesuai ukran jarik. Pemindahan desain ke alat screen dilakukan oleh Perusahaan milik Abud Semanggi di Pasar Kliwon. Persiapan lainnya mempersiapkan meja sablon, larutan malam dingin, screen, rakel. (b) produksi, dengan melakukan penyablonan kain. Proses penyablonan dilakukan dengan menuangkan larutan malam dingin di atas permukaan meja sablon kemudian bagian atas diletakkan screen dan dituangkan larutan malam dingin kembali. Kain yang telah disablon siap untuk diangin-anginkan dan diwarna menggunakan pewarna remasol. Penguncian warna dilakukan dengan menggunakan waterglass. Waktu pengerjaan kain ini 3 hari karena dilakukan dengan sekali pelorodan. (3)finishing, kain yang telah siap akan dikemas dan diserahkan ke pihak instansi.

Selera Konsumen, desain Motif Wahyu Ngawiat sesuai dengan desain dari Griya Batik Sidomulyo, tetapi untuk latar disesuaikan dominan merah. 


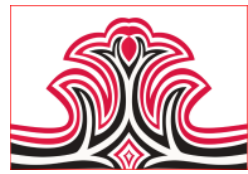

Trend Mode, Motif Wahyu Ngawiat diminati oleh Deskranasda Ngawi karena motifnya yang kecil-kecil dan mencirikhaskan Kabupaten Ngawi. Desainnya bisa digunakan untuk seragam instansi atau perorangan.

Pemasaran, dilakukan secara online melalui whatsapp dan tatap muka agar terjalin komunikasi antara Griya Batik Sidomulyo dengan instansi.

\section{2). Motif Gunungan Ngawi Seragam dari Dinas Pariwisata Pemuda dan Olahraga Ngawi}

Fungsional, Motif Gunungan Ngawi dipesan sebagai seragam oleh Dinas Pariwisata Pemuda dan Olahraga Kabupaten Ngawi. Kain seragam tersebut digunakan sebagai kemeja pria dan rok wanita.

Estetika atau Keindahan, desain Motif Gunungan Ngawi dirancang oleh Suwandi selaku pemilik Griya Batik Sidomulyo. Desain Motif Gunungan Ngawi memiliki corak hias geometris, terlihat pada Motif Lerek sebagai motif pengisinya. Penyusunan Motif Gunungan Ngawi menggunakan prinsip irama pengulangan dari motif, warna, dan ukuran motif yang sama.

Motif utama Gunungan dengan pengisi flora lebih dominan daripada motif lain. Penyusunan kesatuan Motif Gunungan Ngawi tampak pada kesamaankesamaan motif, penebaran warna yang ajeg antara latar dan motif, dan kerapatan pada motif maupun warna. Keseluruhan motif tampak seimbang dan simetris dengan adanya hiasan pinggiran atau tepi di sisi kanan dan kiri kain.

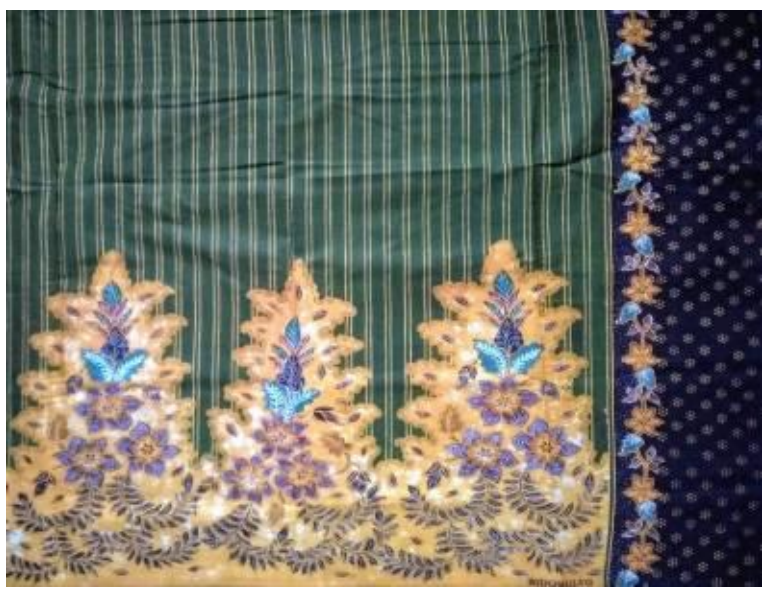

Gambar 2. Kain "Tiruan Batik" Gunungan Ngawi untuk Seragam Dinas Pariwisata Pemuda dan Olahraga Kabupaten Ngawi (Azizah, 2020)

Motif utama Gunungan divisualkan pola hias menyerupai gunung yang meruncing di bagian tengahnya dan di dalamnya terdapat flora seperti daun jati, bambu, dan bunga. Garis-garis lengkung yang
Gorga : Jurnal Seni Rupa

Volume 10 Nomor 01 Januari-Juni 2021

p-ISSN: 2301-5942 | e-ISSN: 2580-2380

meruncing di bagian tengah menunjukkan motif tersebut ialah Motif Gunungan.

Motif pengisi pada kain "tiruan batik" Gunungan Ngawi untuk Dinas Pariwisata Pemuda dan Olahraga berupa Motif Lerek. Motif tersebut berperan sebagai motif pengisi latar pada kain "tiruan batik" Gunungan Ngawi. Motif pengisi lainnya terletak pada hiasan pinggiran berupa tumbuhan menjalar dan isen-isen ceceg pitu. Isen-isen lain pada Motif Gunungan Ngawi berupa ceceg-ceceg dan ceceg pitu.

Goresan malam dingin pada pola Gunungan Ngawi membentuk garis melengkung yang bersifat grafis (calligraphic mark), garis tersebut membentuk sebuah gunung dan terdapat garis lurus sebagai latar pengisi pola. Garis lurus pada pola Gunungan Ngawi di sisi kanan dan kiri kain sebagai batas antara motif utama dan hiasan pinggiran. Penggambaran Pola Gunungan Ngawi dilakukan dengan stilasi motif.

Warna yang diterapkan pada desain "tiruan batik" Pola Gunungan Ngawi untuk Dinas Pariwisata Pemuda dan Olahraga Kabupaten Ngawi ialah dominan hijau dan kuning. Pembauran warna (mixing) dari warna-warna yang digunakan saling memberikan satu unsur warna yang sama, misalnya hijau-kuning. Warna motif lain seperti hijau, hitam, coklat, dan putih untuk sebagian garis klowong maupun isen-isen.

Bahan, menggunakan bahan kain mori primissima 'Tari Kupu-Kupu' dengan kualitas kain lembut, nyaman, dan mudah menyerap keringat. Kain jenis ini mudah diaplikasikan pada pewarna remasol. Bahan lain sebagai pelengkap untuk kain "tiruan batik" yakni pewarna remasol, pasta malam dingin, dan waterglass untuk fiksasi kain. Pewarna remasol tersebut dibeli dari Toko tekstil 'Santoso' di Solo. Komposisi pencampuran warna dilakukan dengan cara eksperimen warna hingga mendekati warna pada desain.

Griya Batik Sidomulyo memproduksi bahan malam dingin dengan menggunakan malam atau lilin sisa dari pelorodan. Malam sisa pelorodan dicampurkan dengan bahan lilin seperti getah pohon damar (mata kucing), gondorukem, kote, paraffin, dan terpentin. Campuran tersebut diencerkan dengan larutan bensin, kemudian diencerkan menggunakan mesin bor.

Proses atau Teknis Pelaksanaan, (a) pra produksi, dengan menyiapkan desain ukuran 1x2 meter sesuai ukran jarik. Pemindahan desain ke alat screen dilakukan oleh Perusahaan milik Abud Semanggi di Pasar Kliwon. Persiapan lainnya mempersiapkan meja 


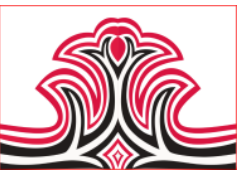

sablon, larutan malam dingin, screen, rakel. (b) produksi, dengan melakukan penyablonan kain. Proses penyablonan dilakukan dengan menuangkan larutan malam dingin di atas permukaan meja sablon kemudian bagian atas diletakkan screen dan dituangkan larutan malam dingin kembali. Kain yang telah disablon siap untuk diangin-anginkan dan diwarna menggunakan pewarna remasol. Penguncian warna dilakukan dengan menggunakan waterglass. Waktu pengerjaan kain ini 4-5 hari karena dilakukan dengan dua kalii pelorodan. (c)finishing, kain yang telah siap akan dikemas dan diserahkan ke pihak instansi.

Selera Konsumen, desain Motif Gunungan Ngawi menggunakan warna yang tidak mencolok dan disesuaikan oleh warna untuk orang dewasa. Trend Mode, desain Motif Gunungan Ngawi bisa digunakan untuk baju dan rok untuk seragam instansi maupun perorangan. Pemasaran, dilakukan secara online melalui whatsapp dan tatap muka agar terjalin komunikasi antara Griya Batik Sidomulyo dengan instansi.

\section{3). Motif Bulus Seragam dari Rumah Sakit Gigi di Ngawi}

Fungsional, Desain yang dipesan sesuai pada keinginan konsumen, namun perlu ditambah logo instansi dari Rumah Sakit Gigi di Ngawi yakni Persatuan Perawat Gigi Indonesia (PPGI) cabang Ngawi. Kain Motif Bulus dipesan untuk baju seragam pegawai pria dan wanita.

Estetika atau Keindahan, desain Motif Bulus dirancang oleh Suwandi selaku pemilik Griya Batik Sidomulyo. Motif Bulus dipilih karena di Kabupaten Ngawi dekat dengan aliran Bengawan Solo maupun Kali Tempuk. Pada kain "tiruan batik" Motif Bulus menggunakan corak hias geometris. Unsur-unsur bangun lingkaran yang disusun membentuk satu kesatuan corak ceplok atau ceplokan. Penyusunan Motif Bulus menggunakan irama pengulangan motif, ukuran motif, dan warna dengan jarak yang teratur.

Motif utama tempurung bulus tampak dominan daripada motif pengisi lainnya. Kesederhanaan motif tampak pada ukuran motif dan bidang segitiga di hiasan pinggiran kain. Kesatuan motif terlihat adanya kesamaan motif, penebaran warna motif yang teratur, dan muncul kerapatan pada motif maupun warna. Keseluruhan motif seimbang dan simetris dengan adanya hiasan pinggiran di sisi kanan kiri kain.
Gorga : Jurnal Seni Rupa

Volume 10 Nomor 01 Januari-Juni 2021

p-ISSN: 2301-5942 | e-ISSN: 2580-2380

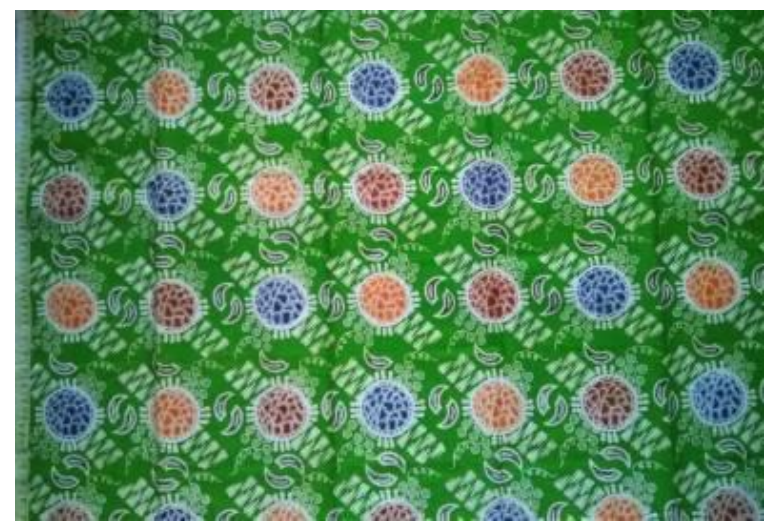

Gambar 3. Kain "Tiruan Batik” Bulus untuk Seragam Rumah Sakit Gigi di Ngawi

(Azizah, 2020)

Motif utama kain "tiruan batik" Bulus yakni hewan bulus atau semacam kura-kura yang terdapat di Tawun. Bangun lingkaran disusun sebagai motif dari tempurung bulus. Motif tersebut nampak bagian yang berwarna putih sebagai simbol gigi untuk Rumah Sakit Gigi di Kabupaten Ngawi. Bentuk lingkaran sebagai visualisasi tempurung bulus pola bulus. Pada bentuk lingkaran terdapat garis lengkung dengan isen-isen ceceg-ceceg. Motif tempurung tersebut terdapat beberapa yang diubah dengan menambahkan logo PPGI cabang Ngawi

Motif pengisi pada Motif Bulus antara lain motif fosil yang menyerupai kaki bulus. Motif lainnya berupa visualisasi gigi dengan warna putih dan rangkaian bunga kecil sebagai variasi pola. Motif gigi dirancang sesuai pesanan Rumah Sakit Gigi Ngawi. Isen-isen pada motif pengisi berupa garis lengkung dan cecegceceg. Pada hiasan pinggiran atau tepi berisi bentuk segitiga kecil yang direfleksikan dan direpetisi sehingga susunannya berkesinambungan.

Hasil goresan malam dingin pada pola Bulus membentuk bidang lingkaran atau ceplok. Penggambaran motif dilakukan dengan stilasi motif bulus dan beberapa motif lainnya. Garis lurus pada kanan dan kiri kain bersifat grafis (calligraphicmark) sebagai pembatas antara motif utama dengan hiasan pinggiran kain.

Warna kain tersebut disesuaikan dengan warna yang telah dipilih oleh Griya Batik Sidomulyo. Pemilihan warna pada kain Motif Bulus tersebut yaitu warna dominan hijau untuk latar, sedangkan warna biru, oranye, putih, dan coklat sebagai warna motif. Karakter warna hijau tampak segar dan hidup, sehingga tepat divisualkan pada latar pola Bulus. Susunan hue berdasarkan klasifikasi warna, susunan warna sekunder hasilnya sedikit kurang kontras dan kurang tajam. 


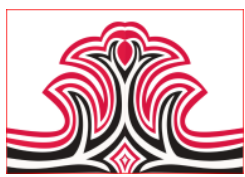

Bahan, menggunakan bahan kain mori primissima merk 'Tari Kupu-Kupu'. Kain yang digunakan merupakan jenis kain mori dengan benang $100 \%$ cotton $50 \mathrm{~s}$ dengan kualitas kain lembut dan mudah diaplikasikan untuk batik maupun "tiruan batik".

Bahan pelengkap untuk kain "tiruan batik" yakni pasta malam dingin, pewarna remasol, dan waterglass untuk fiksasi kain. Pewarna remasol yang digunakan untuk "tiruan batik" Motif Bulus antara lain warna hijau, oranye, coklat, biru, dan hitam. Pencampuran warna dilakukan oleh Griya Batik Sidomulyo dengan cara melakukan percobaan beberapa kali ke dalam kain, sehingga warna sama dengan desain.

Griya Batik Sidomulyo memproduksi bahan malam dingin dengan menggunakan malam atau lilin sisa dari pelorodan. Sisa malam pelorodan akan dicampur dengan bahan lilin dan diencerkan menggunakan bensin. Bahan lilin untuk campuran malam atau lilin sisa pelorodan antara lain getah pohon damar (mata kucing), gondorukem, kote, paraffin, dan terpentin. Alasan Griya Batik Sidomulyo membuat malam dingin sendiri agar tetap terjaga kualitas kainnya.

Proses atau Teknis Pelaksanaan, (a) pra produksi, dengan menyiapkan desain ukuran 1x2 meter sesuai ukran jarik. Pemindahan desain ke alat screen dilakukan oleh Perusahaan milik Abud Semanggi di Pasar Kliwon. Persiapan lainnya mempersiapkan meja sablon, larutan malam dingin, screen, rakel. (b) produksi, dengan melakukan penyablonan kain. Proses penyablonan dilakukan dengan menuangkan larutan malam dingin di atas permukaan meja sablon kemudian bagian atas diletakkan screen dan dituangkan larutan malam dingin kembali. Kain yang telah disablon siap untuk diangin-anginkan dan diwarna menggunakan pewarna remasol. Penguncian warna dilakukan dengan menggunakan waterglass. Waktu pengerjaan kain ini 4-5 hari karena dilakukan dengan dua kali pelorodan dan penambahan logo instansi (c)finishing, kain yang telah siap akan dikemas dan diserahkan ke pihak instansi.

Selera Konsumen, desain Motif Bulus disesuaikan pesanan dari PPGI Ngawi, khususnya pada motif dan tambahan logo instansi.

Trend Mode, desain Motif Bulus bisa digunakan untuk baju dan rok untuk seragam instansi maupun perorangan dengan tanpa mencantumkan logo instansi.
Gorga : Jurnal Seni Rupa

Volume 10 Nomor 01 Januari-Juni 2021

p-ISSN: 2301-5942 | e-ISSN: 2580-2380

Pemasaran, dilakukan secara online melalui whatsapp dan tatap muka agar terjalin komunikasi antara Griya Batik Sidomulyo dengan instansi.

\section{4). Motif Bambu Seragam dari PLKB Ngawi}

Fungsional, desain Motif Bambu dipesan sebagai seragam Petugas Lapangan Keluarga Berencana (PLKB) Kabupaten Ngawi untuk baju pria dan rok wanita.

Estetika atau Keindahan, Motif Bambu merupakan motif "tiruan batik" yang telah diklasifikasikan tentang alam sekitar Kabupaten Ngawi. Desain Motif Bambu dirancang oleh Suwandi selaku pemilik Griya Batik Sidomulyo. Desain "tiruan batik" Bambu memiliki corak hias non geometris, terlihat pada motif utama bambu. Pada motif tersebut divisualisasikan dengan susunan yang tidak terukur meskipun terjadi pengulangan pada seluruh motif. Penyusunan Motif Bambu menggunakan prinsip irama pengulangan dari motif, warna, dan ukuran motif. Motif utama bambu tampak dominan daripada motif pengisi latar. Kesatuan Motif Bambu terlihat pada unsur-unsur kesamaan motif, penebaran warna yang teratur, dan kerapatan pada motif maupun warna. Keseimbangan simetris tampak dengan adanya hiasan pinggiran di tepi kanan dan kiri kain, selain itu keseimbangan tersebut diperoleh dari motif akar yang menjalar ke bawah.

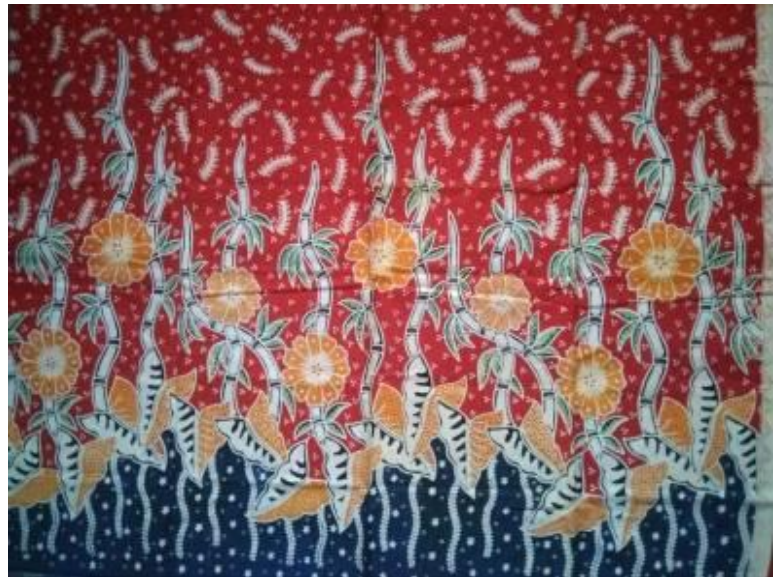

Gambar 4. Kain "Tiruan Batik" Bambu untuk Seragam PLKB Ngawi

(Azizah, 2020)

Motif utama "tiruan batik" Motif Bambu divisualisasikan adanya garis melengkung sebagai visual dari bambu. Motif tersebut dilengkapi oleh daun bambu di setiap ruas batangnya. Pada motif utama terdapat bunga jambu sebagai hiasan dan pangkal bambu terdapat daun jati di bagian bawah bambu. Rangkaian bambu tersebut dilengkapi oleh sulur sebagai visualisasi akar yang menjulur ke bawah. Isen- 


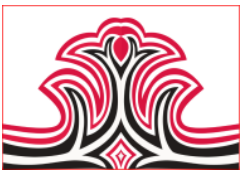

isen pada motif utama bambu berupa sawut, ceceg, ceceg telu, mata dara, dan mlinjon.

Motif pengisi "tiruan batik" Motif Bambu berupa motif padi dan isen-isen ceceg telu. Motif pengisi tersebut sebagai motif pengisi latar pada kain "tiruan batik" Motif Bambu. Isen-isen lain untuk pengisi latar berupa bunga-bunga kecil dan ceceg wolu.

Goresan liin atau malam dingin terdapat garis lengkung yang bersifat grafis (calligraphic mark). Bentuk pada desain dikaitkan dengan adanya penebaran motif, pola, ataupun ragam hias. Penggambaran motif dilakukan dengan stilasi motif. Tampak garis lurus di sisi kanan dan kiri sebagai pembatas antara motif utama dengan hiasan pinggiran.

Warna yang dipesan oleh PLKB Ngawi yaitu warna dominan merah, dari Griya Batik Sidomulyo menambahkan warna lain di setiap motifnya antara lain warna oranye, biru, hitam, putih, dan hijau. Warna putih pada kain tersebut akibat goresan garis dan isenisen motif. Warna merah merupakan warna primer yang cenderung memiliki sifat cerah dan kuat. Goresan garis dengan warna putih dan motif warna hitam, mengakibatkan penetralan warna (neutralizing) sehingga warna tampak lebih menyatu.

Bahan, menggunakan bahan kain mori primissima merk 'Tari Kupu-Kupu'. Kain yang digunakan merupakan jenis kain mori dengan benang $100 \%$ cotton $50 \mathrm{~s}$ dengan kualitas kain lembut dan mudah diaplikasikan untuk batik maupun "tiruan batik".

Bahan pelengkap untuk kain "tiruan batik” yakni pasta malam dingin, pewarna remasol, dan waterglass untuk fiksasi kain. Pewarna remasol yang digunakan untuk "tiruan batik" Motif Bulus antara lain warna hijau, oranye, coklat, biru, dan hitam. Pencampuran warna dilakukan oleh Griya Batik Sidomulyo dengan cara melakukan percobaan warna agar mendekati dan sama dengan desain aslinya.

Griya Batik Sidomulyo memproduksi bahan malam dingin dengan menggunakan malam atau lilin sisa dari pelorodan. Alasan Griya Batik Sidomulyo membuat malam dingin sendiri agar tetap terjaga kualitas kainnya. Sisa malam pelorodan akan dicampur dengan bahan lilin dan diencerkan menggunakan bensin. Bahan lilin untuk campuran malam atau lilin sisa pelorodan antara lain getah pohon damar (mata kucing), gondorukem, kote, paraffin, dan terpentin.

Proses atau Teknis Pelaksanaan, (a) pra produksi, dengan menyiapkan desain ukuran 1x2 meter sesuai
Gorga : Jurnal Seni Rupa

Volume 10 Nomor 01 Januari-Juni 2021

p-ISSN: 2301-5942 | e-ISSN: 2580-2380

ukran jarik. Pemindahan desain ke alat screen dilakukan oleh Perusahaan milik Abud Semanggi di Pasar Kliwon. Persiapan lainnya mempersiapkan meja sablon, larutan malam dingin, screen, rakel. (b) produksi, dengan melakukan penyablonan kain. Proses penyablonan dilakukan dengan menuangkan larutan malam dingin di atas permukaan meja sablon kemudian bagian atas diletakkan screen dan dituangkan larutan malam dingin kembali. Kain yang telah disablon siap untuk diangin-anginkan dan diwarna menggunakan pewarna remasol. Penguncian warna dilakukan dengan menggunakan waterglass. Waktu pengerjaan kain ini 3 hari karena dilakukan dengan sekali pelorodan. (c)finishing, kain yang telah siap akan dikemas dan diserahkan ke pihak instansi.

Selera Konsumen, desain Motif Bambu diminati banyak konsumen karena goresan lilin yang rapi dan motifnya mencirikhaskan Ngawi.

Trend Mode, desain Motif Bambu bisa digunakan untuk baju dan rok seragam untuk instansi maupun perorangan.

Pemasaran, dilakukan secara online melalui whatsapp dan tatap muka agar terjalin komunikasi antara Griya Batik Sidomulyo dengan instansi.

Untuk memudahkan pemahaman tulisan tersebut di atas, di bawah ini hasil analisis beberapa "tiruan batik" print malam dingin di Griya Batik Sidomulyo:

Tabel 1. Hasil Analisis Produk Tiruan Batik (Azizah, 2021)

\begin{tabular}{|c|c|}
\hline POLA & ASPEK PERTIMBANGAN DESAIN \\
\hline \multirow[t]{7}{*}{$\begin{array}{l}\text { Wahyu } \\
\text { Ngawiat }\end{array}$} & $\begin{array}{l}\text { Fungsional : Seragam Ibu-ibu Pegawai } \\
\text { Deskranasda Kabupaten Ngawi. }\end{array}$ \\
\hline & $\begin{array}{l}\text { Estetika : 1) corak non geometris, 2) } \\
\text { penyusunan pengulangan motif, warna, } \\
\text { ukuran, 3) kesatuan motif, warna, dan } \\
\text { kerapatan motif, 4) keseimbangan simetris, } \\
\text { 5) motif utama Wahyu tumurun, 6) motif } \\
\text { pengisi kali tempuk, fosil, bebatuan dan } \\
\text { tana, 7) warna merah-hitam-putih. }\end{array}$ \\
\hline & $\begin{array}{l}\text { Bahan : kain mori primissima 'Tari Kupu- } \\
\text { kupu', pewarna remasol, pasta malam } \\
\text { dingin, waterglass. }\end{array}$ \\
\hline & $\begin{array}{l}\text { Proses : pra-produksi, produksi, dan } \\
\text { finishing. }\end{array}$ \\
\hline & $\begin{array}{l}\text { Selera konsumen : desain sesuai } \\
\text { Deskranasda Ngawi dengan warna latar } \\
\text { merah. }\end{array}$ \\
\hline & $\begin{array}{l}\text { Trend mode : desain pola bisa digunakan } \\
\text { untuk seragam instansi dan perorangan. }\end{array}$ \\
\hline & $\begin{array}{l}\text { Pemasaran : online-Whatsapp-konsultasi } \\
\text { produk. }\end{array}$ \\
\hline
\end{tabular}




\begin{tabular}{|c|c|}
\hline \multirow[t]{7}{*}{$\begin{array}{c}\text { Gunungan } \\
\text { Ngawi }\end{array}$} & $\begin{array}{l}\text { Fungsional : seragam Dinas Pariwisata } \\
\text { Pemuda dan Olahraga Kabupaten Ngawi. }\end{array}$ \\
\hline & $\begin{array}{l}\text { Estetika : 1) corak geometris, 2) } \\
\text { pengulangan motif, warna, ukuran, 3) } \\
\text { dominan, 4) kesatuan motif dan warna, 5) } \\
\text { seimbang simetris, 6) motif utama } \\
\text { gunungan, 7) motif pengisi lerek dan } \\
\text { tumbuhan menjalar, 8) warna hijau-kuning- } \\
\text { coklat-hitam-putih. }\end{array}$ \\
\hline & $\begin{array}{l}\text { Bahan : kain mori primissima 'Tari Kupu- } \\
\text { kupu', pewarna remasol, pasta malam } \\
\text { dingin, malam panas, waterglass. }\end{array}$ \\
\hline & $\begin{array}{l}\text { Proses : pra-produksi, produksi, dan } \\
\text { finishing. }\end{array}$ \\
\hline & $\begin{array}{l}\text { Selera konsumen : desain sesuai Dinas } \\
\text { Pariwisata Pemuda dan Olahraga dengan } \\
\text { warna dominan hijau-kuning. }\end{array}$ \\
\hline & $\begin{array}{l}\text { Trend mode : desain bisa digunakan untuk } \\
\text { seragam instansi dan perorangan. }\end{array}$ \\
\hline & $\begin{array}{l}\text { Pemasaran : online-Whatsapp-konsultasi } \\
\text { produk. }\end{array}$ \\
\hline \multirow[t]{7}{*}{ Bulus } & $\begin{array}{l}\text { Fungsional : seragam Rumah Sakit Gigi di } \\
\text { Ngawi. }\end{array}$ \\
\hline & $\begin{array}{l}\text { Estetika : 1) corak geometris 2) unsur } \\
\text { bangun ceplok/ceplokan 3) pengulangan } \\
\text { motif, warna, dan ukuran 4) kesederhanaan } \\
\text { 5) kesatuan kesamaan motif, warna, } \\
\text { kerapatan 6) keseimbangan simetris 7) } \\
\text { motif utama bulus 8) motif pengisi gigi dan } \\
\text { fosil 9) warna hijau-coklat-oranye-hitam- } \\
\text { putih-biru. }\end{array}$ \\
\hline & $\begin{array}{l}\text { Bahan : kain mori primissima 'Tari Kupu- } \\
\text { kupu', pewarna remasol, pasta malam } \\
\text { dingin, malam panas, waterglass. }\end{array}$ \\
\hline & $\begin{array}{l}\text { Proses : pra-produksi, produksi, dan } \\
\text { finishing. }\end{array}$ \\
\hline & $\begin{array}{l}\text { Selera konsumen : desain sesuai dengan } \\
\text { Rumah Sakit Gigi dengan tambahan motif } \\
\text { logo dan adanya ciri khas visual gigi. }\end{array}$ \\
\hline & $\begin{array}{l}\text { Trend mode: desain bisa digunakan untuk } \\
\text { baju seragam umum tanpa mencantumkan } \\
\text { logo instansi. }\end{array}$ \\
\hline & $\begin{array}{l}\text { Pemasaran : online-whatsapp-konsultasi } \\
\text { produk. }\end{array}$ \\
\hline \multirow[t]{7}{*}{ Bambu } & Fungsional : seragam PLKB Ngawi. \\
\hline & $\begin{array}{l}\text { Estetika : 1) corak non geometris 2) } \\
\text { pengulangan motif, warna, ukuran motif 3) } \\
\text { dominan 4) kesatuan kesamaan motif, } \\
\text { warna, kerapatan 5) keseimbangan motif 6) } \\
\text { motif utama bambu 7) motif pengisi padi } \\
\text { 7) warna merah-biru-putih-oranye-hitam. }\end{array}$ \\
\hline & $\begin{array}{l}\text { Bahan : kain mori primissima 'Tari Kupu- } \\
\text { kupu', pewarna remasol, pasta malam } \\
\text { dingin, waterglass. }\end{array}$ \\
\hline & Proses : pra-produksi, produksi, finishing. \\
\hline & $\begin{array}{l}\text { Selera konsumen : desain mencirikhaskan } \\
\text { Ngawi. }\end{array}$ \\
\hline & $\begin{array}{l}\text { Trend mode : desain cocok untuk baju dan } \\
\text { rok seragam instansi atau perorangan. }\end{array}$ \\
\hline & $\begin{array}{l}\text { Pemasaran : online-whatsapp-konsultasi } \\
\text { produk. }\end{array}$ \\
\hline
\end{tabular}

Hasil analisis data mengenai latar belakang Griya Batik Sidomulyo dalam memproduksi tekstil 'tiruan batik'
Gorga : Jurnal Seni Rupa

Volume 10 Nomor 01 Januari-Juni 2021

p-ISSN: 2301-5942 | e-ISSN: 2580-2380

untuk seragam dipengaruhi adanya kemajuan teknologi untuk proses malam dingin, sehingga tidak membutuhkan banyak karyawan. Produksi 'tiruan batik' print malam dingin memerlukan ide proses kreatif agar terwujudnya hasil kain yang sesuai dengan aspek-aspek pertimbangan desain seperti aspek fungsional sebagai seragam, aspek estetika yang terdapat pada corak maupun warna pada desain, aspek bahan, dan aspek proses produksi print malam dingin dengan selera konsumen, trend mode, dan pemasaran.

\section{KESIMPULAN DAN SARAN}

\section{Kesimpulan}

Latar belakang Griya Batik Sidomulyo memproduksi 'tiruan batik' ialah sedikitnya karyawan dengan mengharuskan memenuhi pesanan, adanya kemajuan teknologi dengan alat sablon atau screen untuk malam dingin mampu mempercepat proses produksi. Griya Batik Sidomulyo memproduksi kain batik sejak tahun 1989 dan sejak tahun 2010 Griya Batik Sidomulyo memproduksi kain "tiruan batik" dengan print malam dingin. Produk "tiruan batik" tersebut telah dijual dan dipesan oleh berbagai instansi swasta maupun pemerintah untuk seragam.

Griya Batik Sidomulyo mempertimbangkan aspekaspek desain dalam merancang "tiruan batik" untuk seragam. Setiap pola kain menerapkan aspek-aspek fungsional, estetika atau keindahan, bahan, dan proses. Aspek tersebut dilengkapi dengan pertimbangan lain seperti selera konsumen, trend mode, dan pemasaran. Kain Motif Wahyu Ngawiat, Motif Gunungan Ngawi, Motif Bulus, dan Motif Bambu digunakan untuk seragam, baik untuk atasan atau bawahan seragam. Bahan-bahan yang digunakan berkaitan dengan proses produksi, seperti kain mori primissima merk Tari Kupu-Kupu, pewarna remasol, larutan malam dingin, dan alat screen maupun rakel sablon. Proses produksi hampir sama, namun terdapat perbedaan pada proses pewarnaan dan pencantingan motif kedua yang mengharuskan melalui proses dua kali pelorodan. Pertimbangan selera konsumen disesuaikan dengan tiap instansi. Trend mode tampak pada kain yang bisa digunakan untuk seragam instansi maupun perorangan. Pemasaran produk dilakukan untuk saling berkomunikasi dalam pemesanan produk, agar hasilnya sesuai pesanan.

Berdasarkan kesimpulan tersebut di atas, produk kain tiruan batik di Griya Batik Sidomulyo memiliki keistimewaan. Hal-hal yang diistimewakan tersebut antara lain waktu produksi yang tepat waktu, visual desain warna yang sesuai dan awet tahan luntur, serta bahan yang dipakai nyaman ketika digunakan. 


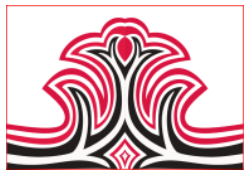

2. Saran

Kajian Desain pada Tekstil Tiruan Batik di Batik Sidomulyo Ngawi sebagai Tekstil untuk Seragam ini diharapkan dapat memberikan sumbangsih dalam pengembangan ilmu pengetahuan di bidang seni rupa dan desain khususnya sebagai referensi di bidang kriya tekstil. Griya Batik Sidomulyo Ngawi diharapkan mampu mempertahankan kualitas kain yang telah ada dan berinovasi dalam memproduksi kain "tiruan batik" print malam dingin dengan motif khas Ngawi, serta menambah pola batik sehingga konsumen mendapat lebih banyak pilihan.

\section{DAFTAR RUJUKAN}

. (2019). Warta BBKB (edisi 6).

Yogyakarta. Balai Besar Kerajinan dan Batik.

Affanti, Tiwi Bina. (2007). Ornamentik. Surakarta: FSSR UNS.

Azizah, S. K. (2020). “Tiruan Batik”. Hasil Dokumentasi Pribadi: 2020, Ngawi.

BSN. (2014). Batik-Pengertian dan Istilah. Jakarta: Badan Standarisasi Nasional.

BSN. (2015). Tiruan Batik dan Paduan Batik dengan Batik-Pengertian dan Istilah. Jakarta: Badan Standarisasi Nasional.

Ibrahim, I.I. (2007). Budaya Populer sebagai Komunikasi: Dinamika Popscape Mediascape di Indoneia Kontemporer. Yogyakarta: Jalasutra.

Lisbijanto, Herry. (2013). Batik. Yogyakarta: Graha Ilmu.

Rizali, Nanang. (2017). Tinjauan Desain Tekstil. Surakarta: UNS Press.

Suharso dan Ana, Retnoningsih. (2005). Kamus Besar Bahasa Indonesia. Semarang: Widya Karya.

Sachari, Agus. (2005). Metodologi Penelitian Budaya Rupa. Jakarta: Erlangga.

Sulaeman, S., \& Suhartini, T. (1988). Penelitian Pengaruh Beberapa Pelarut Organik Dalam Pembuatan Lilin Batik Cair Terhadap Proses Pembatikan. Dinamika Kerajinan dan Batik, (8), 25-29.

Sunaryo, Aryo. (2009). Ornamen Nusantara (Kajian Khusus Tentang Ornamen Indonesia). Semarang: Dahara Prize.

Susanto, Sewan. S.K. (1980). Seni Kerajinan Batik Indonesia. Jakarta: Balai Penelitian Batik dan Kerajinan.

Sutopo, H.B. (2002). Metodologi Penelitian Kualitatif. Surakarta: UNS Press.

Utoyo, J. T., Priyatno, A., \& Azis, A. C. K. (2020). Penerapan Prinsip-Prinsip Seni Rupa Pada Kaligrafi Di Masjid Baiturrahman
Gorga : Jurnal Seni Rupa

Volume 10 Nomor 01 Januari-Juni 2021

p-ISSN: 2301-5942 | e-ISSN: 2580-2380

Unimed. Journal of Education, Humaniora and Social Sciences (JEHSS), 3(2), 419-426.

Van Hoed, V., Zyaykina, N., De Greyt, W., Maes, J., Verhé, R., \& Demeestere, K. (2008). Identification and occurrence of steryl glucosides in palm and soy biodiesel. Journal of the American Oil Chemists' Society, 85(8), 701

Wulandari, Ari. (2011). Batik Nusantara: Makna Filosofis, Cara Pembuatan dan Industri Batik. Yogyakarta: Andi. 